\title{
EUDACTYLINA RACHELAE N.SP., A COPEPOD PARASITIC ON THE ELECTRIC RAY, TORPEDO NOBILIANA BONAPARTE
}

\author{
By J. GREen \\ Bedford College, University of London
}

(Text-fig. I)

Five species of the genus Eudactylina are known from British waters (Scott \& Scott, I913), and of these only one, E. acuta Van Beneden, is recorded in the Plymouth Marine Fauna (Marine Biological Association, 1957, p. I8I). The species described below was found among the gill filaments of a large specimen of Torpedo nobiliana Bonaparte (det. P. G. Corbin) taken in trawl by R.V. Sula off Plymouth in July I957. There were five females.

\section{Eudactylina rachelae n.sp.}

\section{Description of the female}

The body is elongated, maggot-shaped. The length, excluding the egg strings, is $2.3-2.5 \mathrm{~mm}$. When fresh the colour is cream, with the gut showing through brown. The first pedigerous segment is fused with the head, the whole being covered by a single dorsal shield which is one and a third times as long as wide, and somewhat narrowed anteriorly. The second and third pedigerous segments have dorsal shields which are similar in length, while that of the fourth pedigerous segment is longer. The dorsal shield of the fifth pedigerous segment is smaller than those of the second and third. The genital segment is narrower than the preceding segments. The urosome (excluding the genital segment) has two segments; the first being roughly twice as long as the second. The dorsal surface of the body bears numerous crescent-shaped lamellar processes, which look like minute spinules when viewed from the side.

The antennules (Fig. I B) are stout, of five podomeres, the last indistinctly separated from the fourth. The armature is similar to that of E. acuta and $E$. similis. The two principal spines lack the fringe of minute spinules along the upper edge, which is found in E. similis. The large spine on the second podomere has a series of minute crescent-shaped depressions, each of which appears to contain a spinule lying almost parallel to the border of the spine. The large spine on the third podomere has three shallow oblique teeth on each side (Fig. I C).

The antennae (Fig. ID) have four podomeres. The second podomere has a strong spine-like process on the inner side, while the third has two such processes and a seta. The third podomere also bears numerous crescentshaped processes similar to those on the dorsal surface of the body. The 


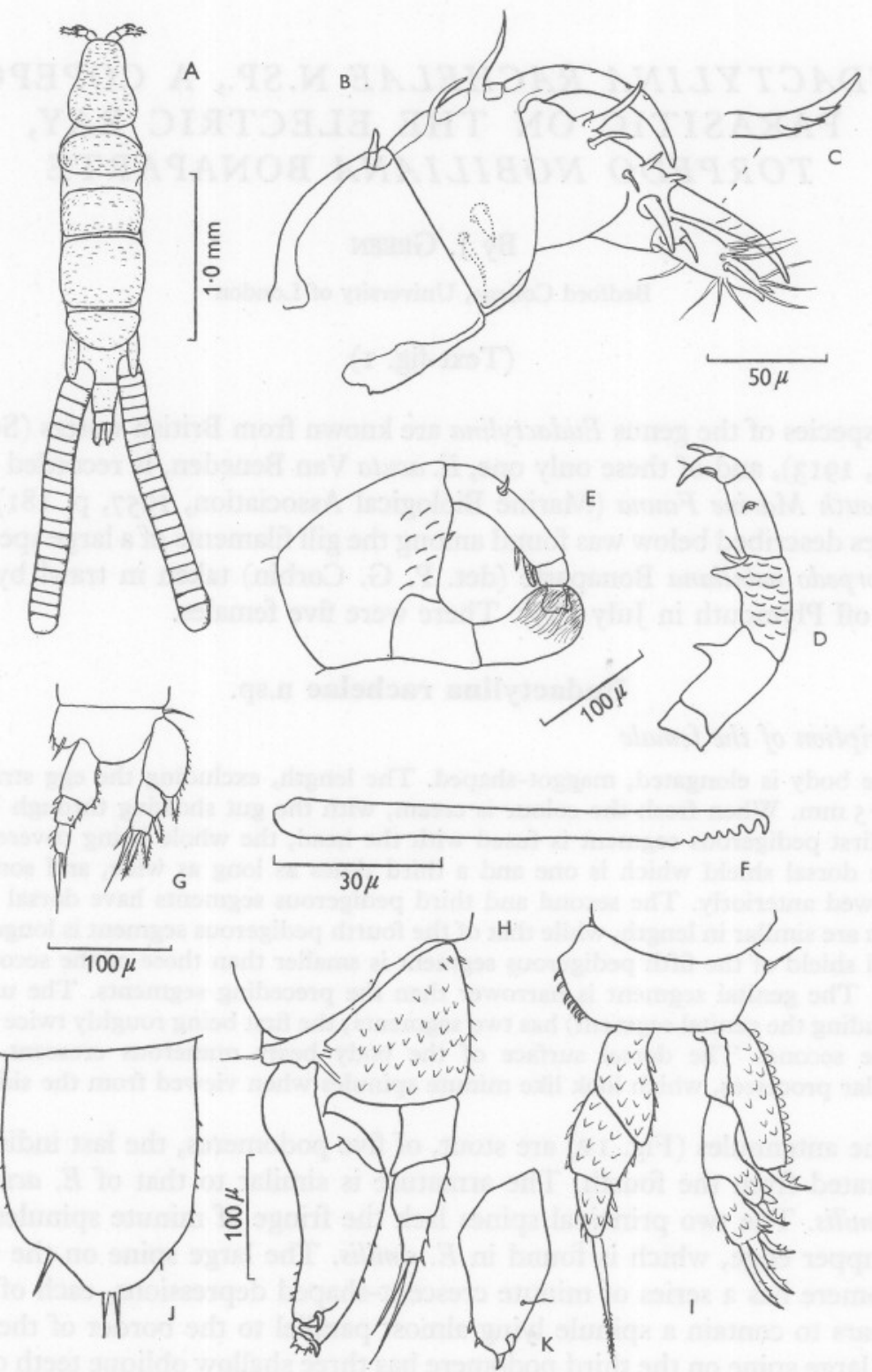

Fig. I. A-K, Eudactylina rachelae n.sp., adult female. A, dorsal view; B, antennule; c, spine on third podomere of antennule; $\mathrm{D}$, antenna; $\mathrm{E}$, second maxilliped; $\mathrm{F}$, mandible; $\mathrm{G}$, first leg; $\mathrm{H}$, second leg; I, third leg; J, fifth leg; $\mathrm{K}$, ventral view of left caudal ramus. G-K are all drawn to the same scale. 
fourth podomere bears what appears to be a sensory pit. The antenna ends in two stout spines and a seta.

The mandible (Fig. I F) is long and straight, with a terminal hook and seven or eight short blunt teeth.

The maxilla, like that of $E$. similis, has two setae on the principal lobe and one on the secondary lobe.

The first maxilliped has three podomeres and terminates in a stout spine with two tufts of setae at its base.

The second maxillipeds (Fig. IE) are large and chelate. The movable branch of the chela ends in an expanded cup-like structure which fits inside the thin, expanded and minutely fluted end of the immovable branch.

The first pair of legs is much smaller than the second to fourth pairs. The second basal podomere has one moderate and two small spines on its inner border. The endopod and exopod each have three podomeres.

The second legs have strongly modified exopods (Fig. I H), while the endopod has three normal podomeres.

The third and fourth legs are similar in structure (Fig. II). The surface of the podomeres is drawn out into flattened spine-like processes which appear as short triangular lamellae when viewed from the side. The strong spines on the exopods are distinctly toothed.

The fifth leg consists of a single plate-like podomere, with three terminal setae and a few spinules along the lateral borders.

The caudal rami are one and a half times as long as the anal segment. Each ramus has two short terminal spines, two weaker inner spines and one feeble outer seta.

\section{Remarks}

This species is closely related to E. similis T. Scott, but can be separated by the differences given in Table $\mathrm{I}$.

TABLE 1

\section{E. similis T. Scott}

Large spine on third podomere of antennule with minute spinules along upper border

Mandible curved

Movable branch of second maxilliped ends in a spine

First legs not much smaller than others. The inner border of the second basal podomere with two stout spines

Spines on third and fourth legs not toothed

Caudal rami without two inner spines
E. rachelae n.sp.

Minute spinules not present on this spine, but three oblique teeth present on each side

Mandible straight

Movable branch of second maxilli-

ped ends in an expanded cup

First legs much smaller than others.

Inner border of the second basal podomere with one moderate and two small spines

Spines on third and fourth legs toothed

Caudal rami with two inner spines

Type material. The holotype and one paratype will be deposited at the British Museum. Three paratypes will be retained in my collection. 
These specimens were collected while working at the Plymouth Marine Laboratory; my thanks are due to the Director and Staff for the facilities provided. My thanks are also due to Dr J. Llewellyn for bringing these copepods to my notice.

\section{SUMMARY}

Eudactylina rachelae n.sp. is described and figured. This copepod was found among the gill filaments of Torpedo nobiliana Bonaparte caught off Plymouth in July 1957.

\section{REFERENCES}

Marine Biological Association, 1957. Plymouth Marine Fauna, 3rd ed.

Scott, T. \& Scotт, A., I913. The British Parasitic Copepoda, Vol. I, 252 pp.; Vol. 2, Plates. London: Ray Society. 